\title{
Doctors as disseminators? Practicing physicians as multipliers for community-based prevention networks in a large city in western Germany
}

\author{
Katharina Kreffter $^{1}$ (D) $\cdot$ Simon Götz ${ }^{1} \cdot$ Stefanie Lisak-Wahl $^{1} \cdot$ Thuy Ha Nguyen $^{1} \cdot$ Nico Dragano $^{1} \cdot$ Simone Weyers $^{1}$
}

Received: 16 March 2021 / Accepted: 18 May 2021 / Published online: 11 June 2021

(C) The Author(s) 2021

\begin{abstract}
Aim Practicing physicians have a special position as disseminators of community-based prevention for children. However, it is unclear to what extent physicians inform parents about programs. The study investigated: To what extent do physicians disseminate information about community-based prevention for children aged 0-7? Do differences exist along family's socioeconomic position (SEP) and immigrant background?

Subject and methods We conducted a retrospective cohort study in a German school entrance examination. Parents were invited to participate in a survey on community-based prevention with information about their awareness and information source. SEP was measured by parental education, immigrant background by country of birth. For nine services types, we counted how often parents named physicians and other professional groups as information sources. To estimate social differences, we calculated adjusted odds ratios (OR) with $95 \%$ confidence interval (CI).

Results Survey participants included 6480 parents (response 65.49\%). Compared to other information sources, physicians were mentioned less frequently. For example, regarding language therapy, $31.2 \%$ of parents were informed by healthcare/social services, and $4.4 \%$ by physicians. Lower educated parents were less frequently informed by physicians about counseling services (OR $0.58 ; 95 \%$ CI 0.46-0.73) compared to higher educated parents. Parents with immigrant background were informed less often about parenting skills courses (OR 0.79; 95\% CI 0.70-0.90) compared to parents without immigrant background, but more often about language therapy (OR 1.47; 95\% CI 1.13-1.91). No further social differences were observed.

Conclusion The role of physicians as disseminators for community-based prevention is expandable. They should promote parenting skills courses in a socially sensitive way.
\end{abstract}

Keywords Child health $\cdot$ Community networks $\cdot$ Prevention $\cdot$ Information dissemination $\cdot$ Socioeconomic factors

\section{Introduction}

Children from socioeconomically disadvantaged families have health risk factors and health complaints more frequently than their peers from families of higher socioeconomic status. They face a higher risk for physical inactivity, poor nutrition and overweight (Inchley et al. 2016), adverse developmental outcomes (Pillas et al. 2014), and mental health problems

Katharina Kreffter

katharina.kreffter@uni-duesseldorf.de

1 Faculty of Medicine, University Hospital Duesseldorf, Centre for Health and Society, Institute of Medical Sociology, Moorenstrasse 5, 40225 Duesseldorf, Germany
(Reiss 2013). Children with an immigrant background are disadvantaged in terms of health. They are more often overweight (Murphy et al. 2017), more often perceive their own health as poor (Santos-Hövener et al. 2019), and face greater barriers to accessing healthcare (Chang 2019) than children with no recent family history of migration.

Consequently, socioeconomically disadvantaged children and those with an immigrant background have a special need for prevention and health promotion. In addition to preventive medicine, this includes community-based prevention with population-based interventions aimed at increasing healthful behaviors and programs addressing changes in the social and physical environment (Institute of Medicine (IOM) 2012).

Despite the need, it is relatively seldom that such families and their children utilize programs (Brophy et al. 2011; Dollman and Lewis 2010; Eickhorst et al. 2016; Khanal 
et al. 2019). This disparity in the use of preventive interventions is referred to as "prevention dilemma" (Bauer and Bittlingmayer 2005).

To address health inequalities and other complex health issues at the community level, integrated approaches have been developed for some time now. This involves cooperation between different sectors, e.g., healthcare, education, social welfare, and government. In these partnerships, networks or coalitions (Hidalgo 2013), different partners combine resources to work toward a common goal. This enables a greater range of services and reduces the number of parallel or competing programs (Janosky et al. 2013).

Physicians are important partners in community-based prevention and health promotion and, within the scope of their professional role, they have different opportunities for participation: They can (1) cooperate with other occupations, (2) inform target groups about community-based programs, and (3) address health equity (Frank and Danoff 2007). There is, however, little evidence as to what extent this is the case. In terms of (1), in the US initiative "Building Blocks Collaborative" (Shrimali et al. 2014), the public health authority functions as an advocate for new community-based initiatives, asserts influence and provides human resources. Another example is found in the Dutch program "Healthy School Approach" (Pucher et al. 2015), where physicians take on coordinating roles between the different sectors in public health services that have clear management structures. In regard to (2), a community-based program to prevent prenatal mercury poisoning was developed in a US study (Callejo and Geer 2012). In this case, physicians imparted specific health information to their patients during routine appointments. In regard to (3), pediatricians in the British prevention program "Sure Start" (Roberts 2000), examined the health status of vulnerable children registered in the program and formulated individual support plans. In the German "prevention networks" (Ehlen et al. 2018), physicians examined children attending daycare centers in disadvantaged neighborhoods to coordinate efforts into one program.

There is virtually no information to be found on informing target groups (2), though primary care physicians are the contact point for young families regarding the first prevention measures in early life, such as screening and immunizations, and such physicians have the trust of parents (Iacobucci 2018). Owing to the long-term relationship they usually have with their patients, these physicians have a strategic position for preventive services (Hulscher et al. 1999). However, it has as yet been unclear to what extent physicians inform parents about community-based programs for prevention and health promotion, or if families with a special need for prevention services, including their children, are being reached. We investigated this question based on a large German city which has established various prevention programs for children and relies on community-based networks. Representative survey data in the context of the school entrance examination (SEE) enable differential social analysis.

The aim of this study is to analyze the extent to which physicians live up to their role as multipliers for communitybased programs in prevention and health promotion. In consideration of social inequalities, we want to answer the following questions: To what extent are different physicians involved in disseminating information about community-based programs in prevention and health promotion for children aged 0-7 and their families? Do differences exist depending on a family's socioeconomic position (SEP) and immigrant background?

\section{Methods}

The questions were investigated within the scope of the SEE. Participation is mandatory for all children aged 5-7 prior to starting school. During this standard medical exam, the preschoolers are screened by the public health authority to identify health and developmental disorders relevant to attending school (Oldenhage et al. 2009; Wahl et al. 2018). Individual data is also collected, such as body mass, pathological findings, and participation in routine medical check-ups and therapies. On this basis, parents are advised about supportive measures.

Based on the standard medical exam in Dusseldorf, a large city in western Germany with over 600,000 inhabitants, we carried out the retrospective cohort study "Gesundheit bei Schuleingang" (Healthy Start to School) from 2016 to 2018 (Wahl et al. 2018). During this time, a total of 9894 children who entered school in 2017 and 2018 were examined by the municipal public health authority. The parents of these children were invited by us to participate in an additional survey on the community-based prevention network in Dusseldorf. The parents were surveyed using a standardized questionnaire that gathered information about their level of awareness and the source of their knowledge of the programs for children's health promotion and prevention from birth to the date of the medical exam. In order to include as many parents as possible, our trained field researchers held questionnaires in six foreign languages, and with 6480 parents who agreed to participate in the survey, the response rate was $65.49 \%$.

The types of community-based programs presented here are the result of an inventory conducted in the community beforehand. By questioning professionals and researching websites, 529 interventions could be identified. These were categorized into nine types, depending on content and method. We tested for collinearity using Pearson correlation coefficient and assumed high correlations $>0.5$ (Cohen 1988). Correlations among the nine types are moderate, except for physical exercise and creative activities $(r=0.518)$ as well as 
physical exercise and parenting courses $(\mathrm{r}=0.527)$. Table 1 provides an overview.

If the parents knew about the various types of programs, they were asked for the source of that knowledge. Parents were asked if they received information from physicians (pediatricians, gynecologists, general practitioners), other healthcare and social services institutions (midwives, home visits by professional service providers, child and youth social services, public health authority, educators), networks (parent meeting places, relatives, friends, acquaintances), media (internet, newspaper, flyers) and other sources, whereby it was possible to choose more than one response. The survey also collected sociodemographic data of the parents and children. All participants signed a written statement of informed consent.

The family's socioeconomic position (SEP) was measured by parental level of education using the academic and occupational training based on the demographic standards. Based on the CASMIN classification (Lechert et al. 2006), families were differentiated between those with a low level of education (at most a secondary school diploma and occupational training, CASMIN classification 1a-c) and those with an average/high level of education (Hoffmeyer-Zlotnik 1997; Wahl et al. 2018). Both parents were asked to name their place of birth. An immigrant background was assumed if at least one parent had not been born in Germany. The reference categories were families in which both parents had been born in Germany (Schenk et al. 2007).

In order to control for the health status of the children we used information on age-appropriate development as recorded during the routine screening checks for five-year-old children ("U9 check-up"; no vs. yes).
First, the frequency $(n ; \%)$ with which the parents identified physicians and other sources of information for all types of programs was determined. This showed the relevance of the physicians in the range of the given information sources. In a second step, the frequency with which pediatricians, gynecologists (Ob-Gyn), and general practitioners (GP) were named as information sources $(n ; \%)$ was analyzed to differentiate between the three medical specialties. The frequencies $(n$; $\%)$ were then calculated for the parents who identified physicians as sources of information; this was done separately for parents with low education as compared to parents with average/high education, as well as for parents with an immigrant background as compared to parents without. Finally, the odds of having been informed by physicians about the various programs were calculated for parents with low versus average/ high levels of education and for parents with versus without an immigrant background. To do this, odds ratios (ORs) with a 95\% confidence interval (CI) were calculated. In the first step, these were mutually adjusted for immigrant status and level of education; and in a second step, additionally for age, gender, and developmental status. Because of multiple outcomes we adopted a Bonferroni corrected $p$ value of $<0.005$ ( 0.05 divided by 9 outcomes) indicating strong evidence for an association. The statistical analysis was carried out with STATA 14.

\section{Results}

The sample includes 3334 boys (51.47\%), the mean age is 5.9 years (standard deviation: 0.27 ). Of the children, $72.76 \%$ were appropriately developed for their age at the time of the standard check-up "U9." A total of $11.50 \%$ of the children had
Table 1 Description of the types of community-based prevention programs in Dusseldorf, Germany

\begin{tabular}{|c|c|}
\hline Program type & Description \\
\hline $\begin{array}{l}\text { Early screening for at-risk } \\
\text { children }\end{array}$ & $\begin{array}{l}\text { Intense early screening in the first year of life and community-based supports for } \\
\text { the upbringing and care of children in disadvantaged families, recruitment in } \\
\text { obstetric clinics }\end{array}$ \\
\hline $\begin{array}{l}\text { Early detection in daycare } \\
\text { centers }\end{array}$ & $\begin{array}{l}\text { Developmental screening, programs to promote dental health at daycare centers in } \\
\text { disadvantaged neighborhoods }\end{array}$ \\
\hline $\begin{array}{l}\text { Speech and language } \\
\text { therapy }\end{array}$ & $\begin{array}{l}\text { Programs to promote speech and language development, daycare centers with a } \\
\text { focus on language, German language courses for parents, early childhood } \\
\text { instruction in foreign languages }\end{array}$ \\
\hline $\begin{array}{l}\text { Physical exercise, games } \\
\text { and sports }\end{array}$ & $\begin{array}{l}\text { Parent/baby courses, play groups, swimming courses, games and physical } \\
\text { movement groups without parents (gymnastics, dance, sports) }\end{array}$ \\
\hline Counseling services & $\begin{array}{l}\text { Advice on specific topics, such as childrearing, nutrition, marriage and partnership; } \\
\text { ad-hoc as required }\end{array}$ \\
\hline Parenting courses & $\begin{array}{l}\text { Birthing classes, first aid training, and other courses meant to strengthen parenting } \\
\text { skills on longer term }\end{array}$ \\
\hline Parent meeting places & $\begin{array}{l}\text { Places for parents to meet as an opportunity to share experiences in a neutral setting } \\
\text { with other parents and skilled staff }\end{array}$ \\
\hline Creative activities & Creative arts and music programs, daycare centers with a special focus \\
\hline Reduced fees & Reduced fees for free-time activities and health programs \\
\hline
\end{tabular}


parents with a low level of education and $53.64 \%$ of the children had an immigrant background. The largest immigrant groups were from Morocco (11.27\%), Poland (10.19\%), and Turkey (5.39\%).

Table 2 shows how many parents had heard of the various programs (degree of familiarity). It also lists how often physicians, healthcare/social services, networks, media or other sources of information informed the parents about each program (multiple responses possible). Overall, the reduced fees (mentioned by $83.1 \%$ of the parents) and the physical exercise, games and sports programs $(80.5 \%)$ were the most wellknown among the parents. The early detection screening for at-risk children was mentioned the least often (6.4\%).

Physicians shared information particularly frequently on parenting courses (mentioned by $21.5 \%$ of the parents) and on counseling services $(21.2 \%)$; on the other hand, physicians very rarely gave information about reduced fees $(2.4 \%)$ or early screening for at-risk children (1.9\%). When comparing physicians with the other sources of information, it was noticeable that they were mentioned comparatively seldom as an information source in reference to a specific program. For instance, $4.4 \%$ of the parents reported that they had been informed by physicians about speech and language therapy, while $31.2 \%$ of the parents were informed of this through healthcare/social services providers. This difference from the other information sources is also evident for parent meeting places $(4.2 \%)$, creative activities $(3.0 \%)$, and reduced fees (2.4\%).

Within the group of physicians, pediatricians are the most frequent source of information for almost all of the programs (Table 3; multiple responses possible). Pediatricians were cited by $18.9 \%$ of parents as the source of information on early screening programs and by $15.5 \%$ of parents as the source of information on counseling services. With one exception: For the courses in parenting skills, parents identified gynecologists $(16.8 \%)$ most frequently as information source.
Otherwise, gynecologists and general practitioners were seldom sources of information, for instance, on early screening and detection programs $(1.3 \%$ and $1.3 \%)$, speech and language therapy $(0.3 \%$ and $0.4 \%)$, creative activities $(0.4 \%$ and $0.3 \%)$, or reduced fees $(0.5 \%$ and $0.3 \%$ ).

Table 4 shows how frequently parents with low levels of education or immigrant backgrounds were informed about the various programs by physicians. For this analytical step, those with missing values for education ( $n=118)$, immigrant status ( $n=416)$, or gender $(n=3)$ were excluded, meaning that a total of 5943 children were included in the analysis. When comparing the raw percentages, it was initially seen that the information for the parents with low education and those with high education is usually comparable (e.g., for exercise programs with $9.9 \%$ vs. $10.7 \%$ and for reduced fees with $2.0 \%$ vs. $2.5 \%)$. Only for counseling services (14.6\% vs. $23.0 \%)$ and parenting courses $(14.2 \%$ vs. $23.1 \%)$ did parents with lower education report having been less frequently informed by physicians. The findings are similar when comparing parents with and without an immigrant background, whereby those with an immigrant background were more often informed by physicians about early screening for at-risk children $(2.4 \%$ vs. $0.9 \%)$ and speech and language therapy (5.4\% vs. $3.5 \%)$. When calculating the odds ratios of having been informed by physicians about the various programs for parents with a low versus an average/high level of education and for parents with versus without an immigrant background, the stepwise adjustment brought no substantial change to the estimates. For this reason, Table 4 presents the fully adjusted odds ratios. The multivariate model also showed that parents with low education more seldom reported having been informed by physicians about counseling services (OR $0.58 ; 0.46-0.7395 \% \mathrm{CI}$ ) or parenting courses (OR 0.60; 0.48-0.76 95\% CI) than parents with a higher level of education. In regard to parenting courses, parents with immigrant backgrounds were also less extensively informed. However, the latter group indicated

Table 2 Frequency of informed parents and the different sources of information (multiple responses possible) $N=6480$

\section{Degree of familiarity Information source}

n $(\%)$

\begin{tabular}{|c|c|c|c|c|c|c|}
\hline \multirow{2}{*}{\multicolumn{2}{|c|}{ Program type }} & \\
\hline & & Physicians & Healthcare /social services & Networks & Media & Other \\
\hline Early screening for at-risk children & $416(6.4)$ & $124(1.9)$ & $182(2.8)$ & $86(1.3)$ & $88(1.4)$ & $67(1.0)$ \\
\hline Early detection in daycare centers & $5169(79.7)$ & $1289(19.9)$ & $3958(61.6)$ & $1089(16.8)$ & $433(6.7)$ & $780(12.0)$ \\
\hline Speech and language therapy & $3685(56.8)$ & $287(4.4)$ & $2020(31.2)$ & $1311(20.2)$ & $1176(18.1)$ & $410(6.3)$ \\
\hline Physical exercise, games and sports & $5217(80.5)$ & $666(10.3)$ & $2181(33.7)$ & $3819(58.9)$ & $3217(49.6)$ & $288(4.4)$ \\
\hline Counseling services & $4450(68.6)$ & $1375(21.2)$ & $2521(38.9)$ & $2661(41.4)$ & $2650(40.9)$ & $388(6.0)$ \\
\hline Parenting courses & $4518(69.7)$ & $1391(21.5)$ & 2567 (39.6) & $1935(29.9)$ & $1702(26.3)$ & $486(7.5)$ \\
\hline Parent meeting places & $4497(69.4)$ & $275(4.2)$ & $2027(31.3)$ & $2108(32.5)$ & $1732(26.7)$ & $886(13.7)$ \\
\hline Creative activities & $4207(64.9)$ & $196(3.0)$ & $1821(28.1)$ & $2543(39.2)$ & $2234(34.5)$ & $401(6.2)$ \\
\hline Reduced fees & $5389(83.1)$ & $153(2.4)$ & $1956(30.2)$ & $2491(38.4)$ & 2329 (35.9) & $713(11.0)$ \\
\hline
\end{tabular}


Table 3 Frequency of physicians as information source according to medical specialty

\begin{tabular}{lccc}
\hline & \multicolumn{2}{l}{ Physician as information source $n(\%)$} & Pediatrician \\
\cline { 2 - 4 } Program type & OB-GYN & GP & $104(1.6)$ \\
\hline Early screening for at-risk children & $30(0.5)$ & $22(0.3)$ & $1226(18.9)$ \\
Early detection in daycare centers & $84(1.3)$ & $87(1.3)$ & $266(4.1)$ \\
Speech and language therapy & $17(0.3)$ & $27(0.4)$ & $609(9.4)$ \\
Physical exercise, games and sports & $101(1.6)$ & $49(0.8)$ & $1005(15.5)$ \\
Counseling services & $759(11.7)$ & $201(3.1)$ & $401(6.2)$ \\
Parenting courses & $1091(16.8)$ & $56(0.9)$ & $222(3.4)$ \\
Parent meeting places & $85(1.3)$ & $16(0.3)$ & $177(2.7)$ \\
Creative activities & $24(0.4)$ & $21(0.3)$ & $131(2.0)$ \\
Reduced fees & $29(0.5)$ & $22(0.3)$ &
\end{tabular}

more frequently that they had been informed by physicians about early screening for at-risk children (OR 2.39; 95\% CI 1.51-3.78) and speech and language therapy (OR 1.47; 95\% CI 1.13-1.91) than parents with no immigrant background. No significant differences along social indicators were seen for the programs involving early detection in daycare centers, physical exercise, games and sports, parent meeting places, creative activities, or reduced fees.

\section{Discussion}

The aim of this study was to investigate the extent to which physicians are involved in the dissemination of information about community-based prevention and health promotion programs. Furthermore, we wanted to ascertain if any differences exist in connection with the socioeconomic position and immigrant status of families.

Table 4 Frequency of parents having been informed by physicians according to SEP;

\begin{tabular}{|c|c|c|c|c|c|c|c|c|}
\hline \multirow[b]{2}{*}{ Program type } & \multirow{2}{*}{$\begin{array}{l}\text { Parents with low } \\
\text { education }(n= \\
657) \\
n(\%)\end{array}$} & \multirow[t]{2}{*}{$\begin{array}{l}\text { Parents with } \\
\text { average/high } \\
\text { education }\end{array}$} & \multicolumn{2}{|c|}{$\begin{array}{l}\text { Ratio for low vs. average/ } \\
\text { high education }\end{array}$} & \multirow{2}{*}{$\begin{array}{l}\text { Parents with } \\
\text { immigrant } \\
\text { background }(n= \\
3148)\end{array}$} & \multirow[t]{2}{*}{$\begin{array}{l}\text { Parents without } \\
\text { immigrant } \\
\text { background }\end{array}$} & \multicolumn{2}{|c|}{$\begin{array}{l}\text { Ratio for immigrant vs. } \\
\text { non-immigrant } \\
\text { background }\end{array}$} \\
\hline & & & OR $(95 \% \mathrm{CI}) *$ & $p$ & & & OR $(95 \% \mathrm{CI})^{* *}$ & $p$ \\
\hline $\begin{array}{l}\text { Early screening } \\
\text { for at-risk } \\
\text { children }\end{array}$ & $19(2.7)$ & 87 (1.6) & $1.28(0.76-2.18)$ & 0.3530 & $77(2.4)$ & $26(0.9)$ & $2.39(1.51-3.78)$ & 0.0002 \\
\hline $\begin{array}{l}\text { Early detection } \\
\text { in daycare } \\
\text { centers }\end{array}$ & $124(18.9)$ & $1076(20.3)$ & $0.88(0.71-1.09)$ & 0.2306 & $644(20.4)$ & $556(19.9)$ & $1.03(0.90-1.17)$ & 0.6880 \\
\hline $\begin{array}{l}\text { Speech and } \\
\text { language } \\
\text { therapy }\end{array}$ & $36(5.5)$ & $232(4.4)$ & $1.06(0.73-1.53)$ & 0.7614 & $170(5.4)$ & $98(3.5)$ & $1.47(1.13-1.91)$ & 0.0042 \\
\hline $\begin{array}{l}\text { Physical } \\
\text { exercise, } \\
\text { games and } \\
\text { sports }\end{array}$ & $65(9.9)$ & $566(10.7)$ & $0.97(0.73-1.28)$ & 0.8246 & $311(9.9)$ & $320(11.4)$ & $0.86(0.73-1.02)$ & 0.0877 \\
\hline $\begin{array}{c}\text { Counseling } \\
\text { services }\end{array}$ & $96(14.6)$ & $1216(23.0)$ & $0.58(0.46-0.73)$ & 0.0000 & $651(20.7)$ & $661(23.6)$ & $0.87(0.77-1.00)$ & 0.0355 \\
\hline $\begin{array}{l}\text { Parenting } \\
\text { courses }\end{array}$ & $93(14.2)$ & $1224(23.1)$ & $0.60(0.48-0.76)$ & 0.0000 & $620(19.7)$ & 697 (24.9) & $0.79(0.70-0.90)$ & 0.0003 \\
\hline $\begin{array}{l}\text { Parent meeting } \\
\text { places }\end{array}$ & $19(2.9)$ & $241(4.6)$ & $0.64(0.40-1.04)$ & 0.0709 & $136(4.3)$ & $124(4.4)$ & $1.05(0.82-1.36)$ & 0.6830 \\
\hline $\begin{array}{l}\text { Creative } \\
\text { activities }\end{array}$ & $17(2.6)$ & $167(3.2)$ & $0.69(0.41-1.57)$ & 0.1597 & $111(3.5)$ & $73(2.6)$ & $1.31(0.96-1.79)$ & 0.0856 \\
\hline Reduced fees & $13(2.0)$ & $132(2.5)$ & $0.70(0.39-1.25)$ & 0.2292 & $86(2.7)$ & $59(2.1)$ & $1.29(0.92-1.83)$ & 0.1440 \\
\hline
\end{tabular}

*adjusted for immigrant status, age, gender, and developmental status at time of the school entrance examination at age 5 ; **adjusted for education, age, gender, and developmental status at time of the school entrance examination at age 5 ; significant values are marked in bold, because of multiple outcomes a Bonferroni corrected $p$-value of $<0.005$ was adopted ( 0.05 divided by 9 outcomes); $\mathrm{CI}=$ confidence interval; $N=5943$ 
As part of a broad survey of parents whose children were entering grade school, it was found that physicians are relatively seldom identified as sources of information on prevention programs in comparison to other disseminators. Physicians impart information comparatively frequently not only on medical programs such as early screening in preschools but also on non-medical interventions in the form of counselings or parenting courses. That early screening for atrisk children is not widely known and that even physicians do not play a major role here is not to be viewed as problematic. These types of programs are especially targeted toward particular families and participants are identified using specific criteria. In contrast, however, the frequency with which information is shared about the existence of reduced fees as an option to enable participation in other programs could be increased.

When differentiating according to prevention needs, it was also seen that families in different social circumstances were reached in comparable measure by physicians for half of the programs and services. However, parents with lower education and parents with an immigrant background were less often informed about counseling services or parenting courses, which can cover a wide range of child health topics. As to be expected, families with an immigrant background are more frequently informed about speech and language therapy, but surprisingly less often about early screening for at-risk children.

How to account for the fact that physicians are underrepresented as sources of information on community-based programs for prevention and health promotion? Some authors refer to the problem that physicians perceive their competency in the area of prevention as low. In a survey of young Australian physicians, 54\% estimated that they lacked competency when it came to informing patients about support groups and information services (Girgis et al. 2001). Raupach et al. (2001) point out that medical education is dominated by curative medicine and has a fragmented view of public health. However, even in places where health advocacy is professionalized in medical education, prejudices exist regarding practical implementation (Dobson et al. 2012). General practitioners identify external obstacles to participation in and dissemination of health promotion interventions, such as time restrictions, aspects of compensation, and insufficient information systems (Leppin 2014; Raupach et al. 2001; Stafford et al. 2010). Lastly, even the patients are not always open to health promotion programs, above all, if the effect of these interventions - in contrast to medical therapies - is not immediately visible (Raupach et al. 2001). When physicians focus first on the issues prioritized by their patients, then health promotion often takes a "backseat" (Calderón et al. 2011).

The increasing interest in the social determinants of health and disease, however, suggests that a new generation of physicians will commit themselves to responding to health problems at the community level (Halliday 2011; Kuo et al. 2011; Sud et al. 2011). Reminder systems (Hulscher et al. 1999) and information databases of community-based services and programs (Kreffter et al. 2019) could assist physicians in finding appropriate programs. Locally, it will be necessary to coordinate approaches so as to include practicing physicians in community-based public health networks. The literature is full of reports and models for building coordinated community-based public health approaches (Fawcett et al. 2010; Janosky et al. 2013). The special role of the physician is hardly taken into account, though. A key to these models is, however, the development of leadership for which physicians could assume an important role. When doing this, opinion leaders should be included who are clearly respected by their medical colleagues (Hulscher et al. 1999). Ideally, a system of fees would be put into place to create incentives for prevention activities (Glaeske et al. 2003; Raupach et al. 2001). The latter is, however, contingent on the type of healthcare system and cannot be easily generalized.

The phenomenon that socioeconomically disadvantaged parents are reached by physicians to a lesser extent than parents with a higher SEP is plausible. Patients with a lower SEP receive less information, less guidance, less socio-emotional support and partnership building efforts from physicians (Willems et al. 2005). The communication style employed by medical doctors is, in turn, influenced by how patients communicate. Middle and higher educated patients more often communicate actively, show more ability to express themselves affectively, and demand more information from their physician (Aelbrecht et al. 2015). Patients with lower SEP are disadvantaged because their physicians incorrectly gauge their desire and need for information, as well as their ability to cooperate in the provision of healthcare (Willems et al. 2005). Verlinde et al. (2012) showed that lower SEP patients exert less control over communication. An active communication style of parents with higher education could explain why these parents are more frequently informed by their physicians about counseling services and courses teaching parenting skills in our study.

What can be done that the physicians practicing in the communities inform families with a specific prevention need, primarily families with low education, to a greater extend? Callejo and Geer (2012) refer to the ideal opportunity physicians could have as the first point of contact for young or pregnant women and to disseminate pertinent health information in the course of routine care. In the course of doing this, however, physicians should first have access to an information system that enables finding efficient, appropriate programs and services. Computer-based systems are superior to the flurry of flyers and brochures, and it is possible to see that such systems are being strived for in large cities where many diverse prevention and health promotion programs exist (Kreffter et al. 2019). The expansion of digital information 
systems for professionals has gotten a digital boost recently and promising approaches have emerged (Cheung et al. 2019; Saaristo et al. 2019). Second, information should be as sensitive as possible to social or cultural issues. This means to recognize specific concepts of health and illness, attitudes, and norms in health communication (Betsch et al. 2016). This also affects materials on health education that communicates basic information to patients in a simple, brief manner or in different languages (Callejo and Geer 2012). In the face of the dominance medical therapies have in the minds of physicians and patients, it remains a challenge to convince families with a lower than average understanding of health issues that non-medical interventions have clear benefits for childhood development and child health (Raupach et al. 2001).

\section{Limitations}

This study is, to our knowledge, the first differentiated analysis of the extent to which physicians inform parents about community-based prevention and health promotion programs. Thereby, we analyzed social disparities in different ways, which is another strength of the study. Connecting this with the school entrance examination gave access to all population groups. With a response rate of $65.49 \%$ not all parents could be reached, but compared to other studies, this rate is in the middle range (Weyers et al. 2018). Furthermore, an intensive recruiting process avoided a bias here. Families with low education and families with immigrant background were not underrepresented (Wahl et al. 2018). A major limitation of the study is its retrospective study design in which the parents were surveyed about past events. Inaccurate memories in regard to the types of programs and the information sources cannot be excluded. Another point of criticism is the categorization of program types. Our typification is the result of the prevention landscape in the given community. Another option could be to categorize according to domains of child health and well-being (Pollard and Lee 2003).

\section{Conclusion}

Despite these limitations this study shows that the potential of physicians in community coalitions has by no means been exhausted. In concrete interactions with parents with a low educational background, physicians should make more mention of the counseling services and parenting courses available for parents. With a wide range of topics these programs could contribute to achieving equality in health equity among children.

Author contributions All authors contributed to the study conception and design. Material preparation and data collection were performed by
Stefanie Lisak-Wahl and Thuy Ha Nguyen, data analysis were performed by Katharina Kreffter and Simon Götz. The first draft of the manuscript was written by Katharina Kreffter and Simone Weyers and all authors commented on previous versions of the manuscript. All authors read and approved the final manuscript.

Funding Open Access funding enabled and organized by Projekt DEAL. This work was supported by the Federal Ministry of Education and Research (grant number 01EL1426C).

Availability of data and material (data transparency) Data and material are not available for third parties.

Code availability (software application or custom code) All analyses were conducted using Stata 14

\section{Declarations}

Ethics approval Approval for the study was granted by the ethics committee of the Duesseldorf University Hospital, with the study numbers $5394(02 / 2016)$ and $5664(08 / 2018)$.

Consent to participate All study participants signed a written statement of informed consent.

Consent for publication All study participants gave informed consent to scientific analysis and publication of study data.

Conflict of interest The authors declare that they have no conflict of interest.

Open Access This article is licensed under a Creative Commons Attribution 4.0 International License, which permits use, sharing, adaptation, distribution and reproduction in any medium or format, as long as you give appropriate credit to the original author(s) and the source, provide a link to the Creative Commons licence, and indicate if changes were made. The images or other third party material in this article are included in the article's Creative Commons licence, unless indicated otherwise in a credit line to the material. If material is not included in the article's Creative Commons licence and your intended use is not permitted by statutory regulation or exceeds the permitted use, you will need to obtain permission directly from the copyright holder. To view a copy of this licence, visit http://creativecommons.org/licenses/by/4.0/.

\section{References}

Aelbrecht K, Rimondini M, Bensing J, Moretti F, Willems S, Mazzi M, Fletcher I, Deveugele M (2015) Quality of doctor-patient communication through the eyes of the patient: variation according to the patient's educational level. Advances in health sciences education theory and practice 20(4):873-884. https://doi.org/10.1007/s10459014-9569-6

Bauer U, Bittlingmayer UH (2005) Wer profitiert von Elternbildung? Zeitschrift für Soziologie der Erziehung und Sozialisation 2005(25):263-280

Betsch C, Böhm R, Airhihenbuwa CO, Butler R, Chapman GB, Haase N, Herrmann B, Igarashi T, Kitayama S, Korn L, Nurm Ü-K, Rohrmann B, Rothman AJ, Shavitt S, Updegraff JA, Uskul AK (2016) Improving medical decision making and health promotion through culture-sensitive health communication: an agenda for 
science and practice. Med Decis Making 36(7):811-833. https://doi. org/10.1177/0272989X15600434

Brophy S, Cooksey R, Lyons RA, Thomas NE, Rodgers SE, Gravenor MB (2011) Parental factors associated with walking to school and participation in organised activities at age 5: analysis of the millennium cohort study. BMC Public Health 11:14. https://doi.org/10. 1186/1471-2458-11-14

Calderón C, Balagué L, Cortada JM, Sánchez A (2011) Health promotion in primary care: how should we intervene? A qualitative study involving both physicians and patients. BMC Health Serv Res 11:62. https://doi.org/10.1186/1472-6963-11-62

Callejo FP, Geer LA (2012) A community-based approach to disseminate health information on the hazards of prenatal mercury exposure in Brooklyn, NY. J Community Health 37(4):745-753. https://doi.org/ 10.1007/s10900-012-9575-7

Chang CD (2019) Social determinants of health and health disparities among immigrants and their children. Curr Probl Pediatr Adolesc Health Care 49(1):23-30. https://doi.org/10.1016/j.cppeds.2018.11. 009

Cheung KL, Durusu D, Sui X, de Vries H (2019) How recommender systems could support and enhance computer-tailored digital health programs: a scoping review. Digit Health 5:2055207618824727. https://doi.org/10.1177/2055207618824727

Cohen J (1988) Statistical power analysis for the behavioral sciences, 2nd edn. Erlbaum, Hillsdale

Dobson S, Voyer S, Regehr G (2012) Perspective: agency and activism: rethinking health advocacy in the medical profession. Acad Med 87(9):1161-1164. https://doi.org/10.1097/ACM. 0b013e3182621c25

Dollman J, Lewis NR (2010) The impact of socioeconomic position on sport participation among south Australian youth. J Sci Med Sport 13(3):318-322. https://doi.org/10.1016/j.jsams.2009.04.007

Ehlen S, Dreiskämper D, Utesch T, Rehaag R (2018) Integrierte Gesamtansätze kommunaler Gesundheitsförderung für Kinder. Prävention und Gesundheitsförderung 13(3):254-260. https://doi. org/10.1007/s11553-018-0640-7

Eickhorst A, Schreier A, Brand C, Lang K, Liel C, Renner I, Neumann A, Sann A (2016) Inanspruchnahme von Angeboten der Frühen Hilfen und darüber hinaus durch psychosozial belastete Eltern. Bundesgesundheitsblatt, Gesundheitsforschung, Gesundheitsschutz 59(10):1271-1280. https://doi.org/10.1007/s00103-016-2422-8

Fawcett S, Schultz J, Watson-Thompson J, Fox M, Bremby R (2010) Building multisectoral partnerships for population health and health equity. Prev Chronic Dis 7(6)

Frank JR, Danoff D (2007) The CanMEDS initiative: implementing an outcomes-based framework of physician competencies. Medical teacher 29(7):642-647. https://doi.org/10.1080/ 01421590701746983

Girgis A, Sanson-Fisher RW, Walsh RA (2001) Preventive and other interactional skills of general practitioners, surgeons, and physicians: perceived competence and endorsement of postgraduate training. Prev Med 32(1):73-81. https://doi.org/10.1006/pmed.2000. 0781

Glaeske G, Francke R, Kirschner K, Kolip P (2003) Mühlenbruch S. Prävention und Gesundheitsförderung stärken und ausbauen, Bonn

Halliday M (2011) Do medical professionalism and medical education involve commitments to political advocacy? Acad Med 86(9):1063; author reply 1065. https://doi.org/10.1097/ACM. 0b013e3182299ec6

Hidalgo B (2013) Community coalitions. In: Gellman MD, Turner JR (eds) Encyclopedia of behavioral medicine. Springer, New York, pp $469-472$

Hoffmeyer-Zlotnik J (1997) Das Erfassen von "Bildung" im interkulturellen Vergleich. In: Hradil S (ed) Differenz und Integration: Die Zukunft moderner Gesellschaften Verhandlungen des 28. Kongresses der Deutschen Gesellschaft für Soziologie in Dresden 1996. Campus Verlag, Frankfurt [etc], pp 908-925

Hulscher ME, Wensing M, Grol RP, van der Weijden T, van Weel C (1999) Interventions to improve the delivery of preventive services in primary care. Am J Public Health 89(5):737-746. https://doi.org/ 10.2105/AJPH.89.5.737

Iacobucci G (2018) Trust in GPs remains high but patients report more difficulties getting an appointment. BMJ (Clinical research ed) 362: k3488. https://doi.org/10.1136/bmj.k3488

Inchley J, Currie D, Young T (eds) (2016) Growing up unequal: gender and socioeconomic differences in young people's health and wellbeing; health behaviour in school-aged children (HBSC) study: international report from the 2013/2014 survey. Health policy for children and adolescents no. 7. World Health Organization, Regional Office for Europe, Copenhagen

Institute of Medicine (IOM) (2012) An integrated framework for assessing the value of community-based prevention. National Academies Press, Washington, DC

Janosky JE, Armoutliev EM, Benipal A, Kingsbury D, Teller JLS, Snyder KL, Riley P (2013) Coalitions for impacting the health of a community: the Summit County, Ohio, experience. Popul Health Manag 16(4):246-254. https://doi.org/10.1089/pop.2012.0083

Khanal S, Choi L, Innes-Hughes C, Rissel C (2019) Dose response relationship between program attendance and children's outcomes in a community based weight management program for children and their families. BMC Public Health 19(1):716. https://doi.org/10. 1186/s12889-019-7094-5

Kreffter K, Wahl S, Dragano N, Weyers S (2019) Familien mit Bedarf sind Familien, auf die wir zugehen müssen.: Eine partizipative Bedarfsanalyse zur kommunalen Prävention für sozioökonomisch benachteiligte Kinder. Präv Gesundheitsf 25(3):263. https://doi. org/10.1007/s11553-019-00733-4

Kuo AA, Arcilla L, Castro A, Chen L, Edison B, Huang J, Mitha K, Orkin M, Tejani Z, Tu D, Yeh J, Watt M, Wells L, Coller RJ, Guerrero AD, Slusser WM (2011) Do medical professionalism and medical education involve commitments to political advocacy? Acad Med 86(9):1061-1062; author reply 1065. https://doi.org/10. 1097/ACM.0b013e31822673dc

Lechert Y, Schroedter J, Lüttinger P (2006) Die Umsetzung der Bildungsklassifikation CASMIN für die Volkszählung 1970, die Mikrozensus- Zusatzerhebung 1971 und die Mikrozensen 19762004: Methodenbericht 2006/12, Mannheim

Leppin A (2014) Konzepte und Strategien der Prävention. In: Hurrelmann K, Klotz T, Haisch J (eds) Lehrbuch Prävention und Gesundheitsförderung, 4th edn. Verlag Hans Huber, Bern

Murphy M, Robertson W, Oyebode O (2017) Obesity in international migrant populations. Curr Obes Rep 6(3):314-323. https://doi.org/ 10.1007/s13679-017-0274-7

Oldenhage M, Daseking M, Petermann F (2009) Erhebung des Entwicklungsstandes im Rahmen der arztlichen Schuleingangsuntersuchung. Gesundheitswesen (Bundesverband der Arzte des Offentlichen Gesundheitsdienstes (Germany)) 71(10):638-647. https://doi.org/10.1055/s-0029-1239514

Pillas D, Marmot M, Naicker K, Goldblatt P, Morrison J, Pikhart H (2014) Social inequalities in early childhood health and development: a European-wide systematic review. Pediatric Res 76:418 424. https://doi.org/10.1038/pr.2014.122

Pollard EL, Lee PD (2003) Child well-being: a systematic review of the literature. Soc Indic Res 61(1):59-78. https://doi.org/10.1023/A: 1021284215801

Pucher KK, Candel MJJM, Krumeich A, Boot NMWM, de Vries NK (2015) Effectiveness of a systematic approach to promote intersectoral collaboration in comprehensive school health promotion-a multiple-case study using quantitative and qualitative data. BMC Public Health 15:613. https://doi.org/10.1186/s12889015-1911-2 
Raupach J, Rogers W, Magarey A, Lyons G, Kalucy L (2001) Advancing health promotion in Australian general practice. Health Educ Behav 28(3):352-367. https://doi.org/10.1177/109019810102800309

Reiss F (2013) Socioeconomic inequalities and mental health problems in children and adolescents: a systematic review. Soc Sci Med 90:24 31. https://doi.org/10.1016/j.socscimed.2013.04.026

Roberts H (2000) What is sure start? Arch Dis Child 82(6):435-437. https://doi.org/10.1136/adc.82.6.435

Saaristo V, Hakamäki PES, Ikonen JK, Saukko NS, Wiss KK, Ståhl TP (2019) TEAviisari - benchmarking health promotion capacitybuilding in Finnish municipalities. Eur J Publ Health 29(Suppl_4). https://doi.org/10.1093/eurpub/ckz185.528

Santos-Hövener C, Kuntz B, Frank L, Koschollek C, Ellert U, Hölling H, Thamm R, Schienkiewitz A, Lampert T (2019) Zur gesundheitlichen Lage von Kindern und Jugendlichen mit Migrationshintergrund in Deutschland Ergebnisse aus KiGGS Welle 2. Bundesgesundheitsblatt, Gesundheitsforschung, Gesundheitsschutz 62(10):1253-1262. https://doi.org/10.1007/ s00103-019-03012-x

Schenk L, Ellert U, Neuhauser H (2007) Kinder und Jugendliche mit Migrationshintergrund in Deutschland. Methodische Aspekte im Kinder- und Jugendgesundheitssurvey (KiGGS). Bundesgesundheitsbl Gesundheitsforsch Gesundheitsschutz 50(56):590-599. https://doi.org/10.1007/s00103-007-0220-z

Shrimali BP, Luginbuhl J, Malin C, Flournoy R, Siegel A (2014) The building blocks collaborative: advancing a life course approach to health equity through multi-sector collaboration. Matern Child Health J 18(2):373-379. https://doi.org/10.1007/s10995-013-1278-
Stafford S, Sedlak T, Fok MC, Wong RY (2010) Evaluation of resident attitudes and self-reported competencies in health advocacy. BMC Med Educ 10:82. https://doi.org/10.1186/1472-6920-10-82

Sud SR, Barnert ES, Waters E, Simon P (2011) Do medical professionalism and medical education involve commitments to political advocacy? Acad Med 86(9):1061; author reply 1065. https://doi.org/ 10.1097/ACM.0b013e3182263eca

Verlinde E, de Laender N, de Maesschalck S, Deveugele M, Willems S (2012) The social gradient in doctor-patient communication. Int $\mathrm{J}$ Equity Health 11:12. https://doi.org/10.1186/1475-9276-11-12

Wahl S, Kreffter K, Frölich S, Müller-Thur K, Dragano N, Göbels K, Poschkamp T, Schäfer M, Weyers S (2018) Die Schuleingangsuntersuchung als Türöffner für die gesundheitswissenschaftliche Forschung?: Eine Analyse zur Studienteilnahme ,schwer erreichbarer" Bevölkerungsgruppen. Bundesgesundheitsblatt, Gesundheitsforschung, Gesundheitsschutz 61(10):1236-1241. https://doi.org/10.1007/s00103-018-2808-x

Weyers S, Wahl S, Dragano N, Müller-Thur K (2018) Ist der Datenschatz schon gehoben?: Eine Übersichtsarbeit zur Nutzung der Schuleingangsuntersuchung für die Gesundheitswissenschaften. Prävention und Gesundheitsförderung 13:261-268. https://doi.org/ 10.1007/s11553-018-0641-6

Willems S, de Maesschalck S, Deveugele M, Derese A, de Maeseneer J (2005) Socio-economic status of the patient and doctor-patient communication: does it make a difference? Patient Educ Couns 56(2): 139-146. https://doi.org/10.1016/j.pec.2004.02.011

Publisher's note Springer Nature remains neutral with regard to jurisdictional claims in published maps and institutional affiliations. 